\title{
Para-Siletanylbenzylidene Acetal: Oxidizable Protecting Group for Diols
}

Sarah E. House, Kevin W. C. Poon, Hubert Lam, and Gregory B. Dudley* Department of Chemistry and Biochemistry, Florida State University, Tallahassee, Florida 32306-4390

\section{Supporting Information}

\section{Table of Contents}

General Procedures.......................................... S2

para-siletanylbenzylidene acetal (1) S2

benzylidene acetal (3) $\quad \mathrm{S} 3$

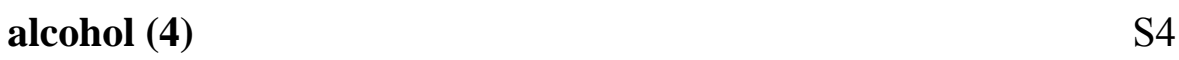

diallylmethyl glucopyranoside (5) S5-6

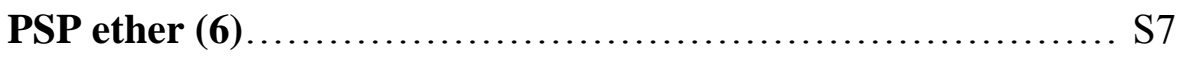

$\begin{array}{ll}\text { PSB ether (7) } & \text { S8 }\end{array}$

$\begin{array}{ll}\text { PSB ether (7) to diol (5) } & \text { S9-10 }\end{array}$

PSP acetal (6) to diol (5) S S10-11

$\begin{array}{ll}\text { alcohol (13) } & \mathrm{S} 11-12\end{array}$

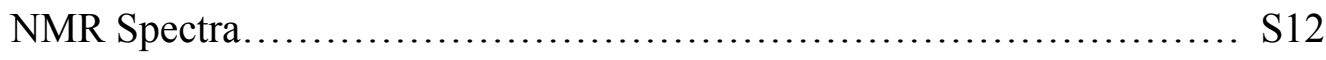

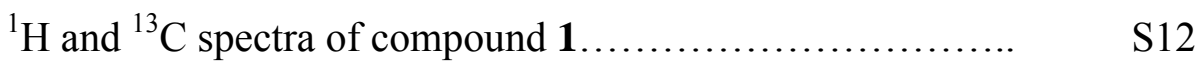

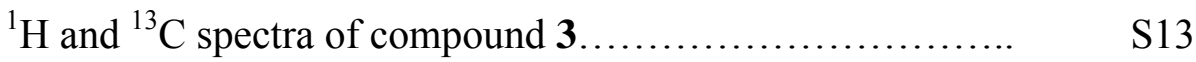

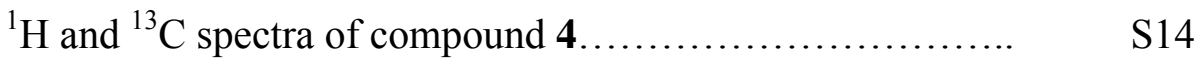

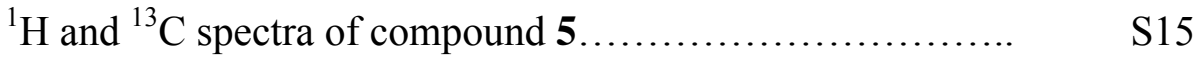

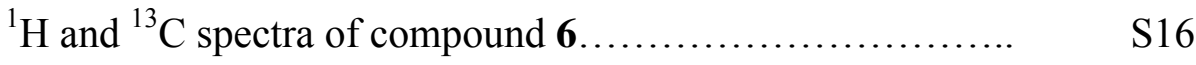

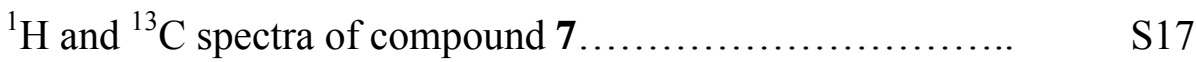

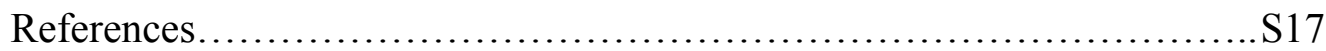




\section{Experimental section}

All the chemicals were used as received unless otherwise stated. Diethyl ether, THF, and $\mathrm{CH}_{2} \mathrm{Cl}_{2}$ were by passage through a neutral alumina and $4 \AA$ molecular sieves columns under argon atmosphere before use. The Grignard reagents were purchased or prepared from the corresponding alkyl or aryl bromides and magnesium turnings, and titrated using a solution of $\mathrm{I}_{2}$ in THF or $\mathrm{Et}_{2} \mathrm{O}$. The purifications of the compounds were performed on flash chromatography using silica gel F-254 (230-400 mesh particle size).

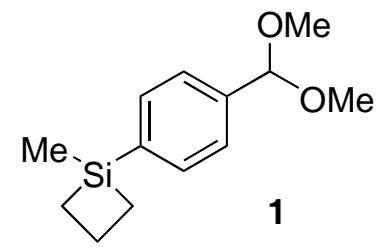

\section{Synthesis of para-siletanylbenzylidene acetal (1).}

Magnesium turnings $(146 \mathrm{mg}, 6.00 \mathrm{mmol})$ and iodine $(21.1 \mathrm{mg}, 0.0800 \mathrm{mmol})$ were placed in an oven-dried two-neck round bottom flask with a stir bar under argon. THF (1.50mL) was added followed by 1,2-dibromoethane $(50.0 \mu \mathrm{L}, 0.320 \mathrm{mmol})$. The mixture was then cooled to $0{ }^{\circ} \mathrm{C}$ in an ice bath for $10 \mathrm{~min}$. 1-Chloro-1-methylsilacyclobutane $(340 \mu \mathrm{L}$, 2.80mmol) was added dropwise to solution. 4-Bromobenzaldehyde dimethyl acetal $(350 \mu \mathrm{L}, 2.09 \mathrm{mmol})$ was dissolved in THF $(5.0 \mathrm{~mL})$ in an addition funnel. This solution was added dropwise over $45 \mathrm{~min}$ at $0{ }^{\circ} \mathrm{C}$. The reaction mixture was stirred at $0{ }^{\circ} \mathrm{C}$ for $1 \mathrm{~h}$ and then warmed to room temperature for overnight. The reaction mixture was quenched with water $(5.0 \mathrm{~mL})$ and extracted with diethyl ether $(5.0 \mathrm{~mL}$ x 3$)$. The combined organic layers were washed with brine $(5.0 \mathrm{~mL})$, dried over $\mathrm{MgSO}_{4}$, filtered and concentrated under vacuum. Purification by flash column chromatography on silica gel (Hexanes/EtOAc: 9/1) provided 0.450g (91\%) of $\mathbf{1}$ as a colorless oil. IR $v_{\max } \mathrm{cm}^{-1} 2931$, 
1725, 1693, 1389, 1281, 1187, 1097, 867, 772. ${ }^{1} \mathrm{HNMR}\left(300 \mathrm{MHz}, \mathrm{CDCl}_{3}\right) \delta 7.65(\mathrm{~d}, J=$ $7.8 \mathrm{~Hz}, 2 \mathrm{H}), 7.46$ (d, J = 7.8 Hz, 2H), 5.40 (s, 1H), 3.34 (s, 6H), 2.19 (q, 2H), 1.35-1.12 (m, 4H), $0.55(\mathrm{~s}, 3 \mathrm{H}) .{ }^{13} \mathrm{CNMR}\left(75 \mathrm{MHz}, \mathrm{CDCl}_{3}\right) \delta$ 139.2, 139.0, 133.4, 126.2, 103.1, 52.7, 18.2, 14.3, -1.77. HRMS (EI) found 236.1235 (M) (calcd for $\mathrm{C}_{13} \mathrm{H}_{20} \mathrm{O}_{2} \mathrm{Si}$ : 236.1233).

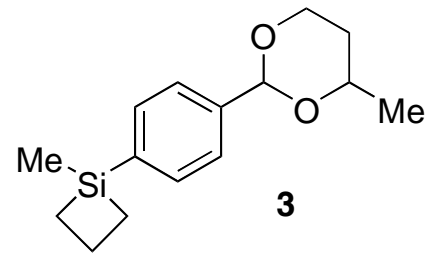

\section{Synthesis of benzylidene acetal (3).}

Compound 1 (158mg, $0.670 \mathrm{mmol})$ and 1,3-butanediol $(50.0 \mu \mathrm{L}, 0.560 \mathrm{mmol})$ were dissolved in $\mathrm{CH}_{2} \mathrm{Cl}_{2}(2.0 \mathrm{~mL})$, followed by CSA $(9.30 \mathrm{mg}, 0.040 \mathrm{mmol})$. The reaction mixture was heated to reflux for $3 \mathrm{~h}$. The solution was cooled to room temperature and quenched with $\mathrm{Et}_{3} \mathrm{~N}$ (10 drops) followed by removal of solvents under vacuum. Purification by flash column chromatography on silica gel (Hexanes/EtOAc: 40/1) provided 0.143g (99\%).of 3 as a clear oil. IR $v_{\max } \mathrm{cm}^{-1} 3428,2967,2929,2855,1719$, $1388,1374,1279,1166,1104,924,899,868 .{ }^{1} \mathrm{HNMR}\left(300 \mathrm{MHz}, \mathrm{CDCl}_{3}\right) \delta 7.63(\mathrm{~d}, J=$ $8.1 \mathrm{~Hz}, 2 \mathrm{H}), 7.52(\mathrm{~d}, J=7.8 \mathrm{~Hz}, 2 \mathrm{H}), 5.52(\mathrm{~s}, 1 \mathrm{H}), 4.26(\mathrm{dd}, J=11.4,5.1 \mathrm{~Hz}, 1 \mathrm{H}), 4.04-$ $3.92(\mathrm{~m}, 2 \mathrm{H}), 2.21-2.11(\mathrm{~m}, 2 \mathrm{H}), 1.81$ (apparent qd, $J=12,5.1 \mathrm{~Hz}, 1 \mathrm{H}), 1.54(\mathrm{bd}, J=$ $13.2 \mathrm{~Hz}, 1 \mathrm{H}), 1.32(\mathrm{~d}, J=6.3 \mathrm{~Hz}, 3 \mathrm{H}), 1.29-1.10(\mathrm{~m}, 4 \mathrm{H}), 0.53(\mathrm{~s}, 3 \mathrm{H}) .{ }^{13} \mathrm{CNMR}$ $\left(75 \mathrm{MHz}, \mathrm{CDCl}_{3}\right) \delta 139.8,139.1,133.4,125.5,101.2,73.4,67.0,32.9,21.7,18.2,14.3,-$ 1.64. HRMS (FAB+) found $285.1290(\mathrm{M}+\mathrm{Na})$ (calcd for $\mathrm{C}_{15} \mathrm{H}_{22} \mathrm{O}_{2} \mathrm{SiNa}$ : 285.1287). 


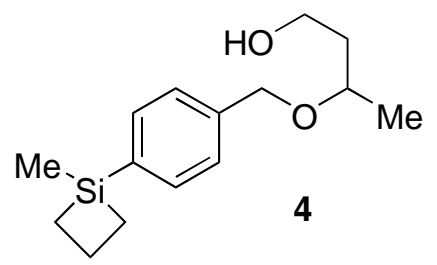

\section{Synthesis of alcohol (4).}

Compound 3 (90mg, $0.340 \mathrm{mmol}$ ) was dissolved in $\mathrm{CH}_{2} \mathrm{Cl}_{2}$ under argon, and the solution was cooled to $-78{ }^{\circ} \mathrm{C}$ in an acetone/dry-ice bath for $5 \mathrm{~min}$. DIBAL-H in $1.0 \mathrm{M}$ heptane $(1.20 \mathrm{~mL}, 1.20 \mathrm{mmol})$ was added dropwise at $-78{ }^{\circ} \mathrm{C}$, and the mixture was warmed to room temperature for overnight. $\mathrm{HCl}(1.0 \mathrm{M}, 20 \mathrm{~mL})$ was added dropwise to the solution at $0{ }^{\circ} \mathrm{C}$, and the organic layer was removed. The aqueous layer was extracted with $\mathrm{CH}_{2} \mathrm{Cl}_{2}(20 \mathrm{~mL} \times 2)$, and the combined organic layers were washed with saturated $\mathrm{NaHCO}_{3}(20 \mathrm{~mL})$, brine $(10 \mathrm{~mL})$, dried over $\mathrm{MgSO}_{4}$, filtered and concentrated under vacuum. Purification by flash column chromatography on silica gel (Hexanes/EtOAc: 3/1) provided 0.0884g (97\%) of 4 as a yellow liquid. IR $v_{\max } \mathrm{cm}^{-1} 3400,2964,1375$, 1251, 1106, 867, 770. ${ }^{1} \mathrm{HNMR}\left(300 \mathrm{MHz}, \mathrm{CDCl}_{3}\right) \delta 7.61(\mathrm{~d}, J=7.8 \mathrm{~Hz}, 2 \mathrm{H}), 7.37(\mathrm{~d}, J=$ $7.8 \mathrm{~Hz}, 2 \mathrm{H}), 4.66(\mathrm{~d}, J=11.3 \mathrm{~Hz}, 1 \mathrm{H}), 4.46(\mathrm{~d}, J=11.7 \mathrm{~Hz}, 1 \mathrm{H}), 3.86-3.75(\mathrm{~m}, 3 \mathrm{H}), 2.46$ (dd, $J=6.3,4.5 \mathrm{~Hz}, 1 \mathrm{H}), 2.18(\mathrm{q}, 2 \mathrm{H}), 1.79(\mathrm{q}, 2 \mathrm{H}), 1.34-1.11(\mathrm{~m}, 4 \mathrm{H}, \mathrm{d}, J=6.0 \mathrm{~Hz}, 3 \mathrm{H})$,

$0.54(\mathrm{~s}, 3 \mathrm{H}) .{ }^{13} \mathrm{CNMR}\left(75 \mathrm{MHz}, \mathrm{CDCl}_{3}\right) \delta 139.6,137.9,133.6,127.1,74.6,70.27,60.7$, $38.8,19.9,18.2,14.3,-1.78$. HRMS $(\mathrm{FAB}+)$ found $287.1438(\mathrm{M}+\mathrm{Na})$ (calcd for $\left.\mathrm{C}_{15} \mathrm{H}_{24} \mathrm{O}_{2} \mathrm{SiNa}: 287.1443\right)$. 


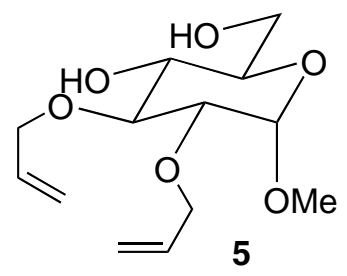

\section{Synthesis of diallylmethyl glucopyranoside (5).}

$(+)-(4,6-O-B e n z y l i d e n e) m e t h y l \quad \alpha-D-g l u c o p y r a n o s i d e \quad(992.7 \mathrm{mg}, \quad 3.52 \mathrm{mmol}) \quad$ was dissolved in DMF (3.0 mL) in an oven-dried round bottom flask under argon followed by tetrabutylammonium iodide (TBAI, $126 \mathrm{mg}, 0.034 \mathrm{mmol}$ ). The mixture was cooled to 0 ${ }^{\circ} \mathrm{C}$ for $5 \mathrm{~min}$ and then cannulated to a suspension of $\mathrm{NaH}$ (356mg, 8.90mmol) in DMF (3.0mL) at $0{ }^{\circ} \mathrm{C}$. This solution was stirred for $0.5 \mathrm{~h}$ at $0{ }^{\circ} \mathrm{C}$ and then allylbromide $(2.50 \mathrm{~mL}, 28.9 \mathrm{mmol})$ was added at this temperature. The reaction was warmed to room temperature for $5 \mathrm{~h}$, and saturated $\mathrm{NH}_{4} \mathrm{Cl}(25 \mathrm{~mL})$ was added at $0{ }^{\circ} \mathrm{C}$. The organic layer was removed, and the aqueous layer was extracted with $\mathrm{CH}_{2} \mathrm{Cl}_{2}(25 \mathrm{~mL} \times 2)$. The combined organic layers were then washed with brine, dried over $\mathrm{MgSO}_{4}$, filtered, and concentrated under vacuum. Purification by flash column chromatography on silica gel (Hexanes/EtOAc: 6/1) provided $1.19 \mathrm{~g}$ (93\%) of the diallyl benzylidene glucose

compound as a white solid. ${ }^{1} \mathrm{HNMR}\left(300 \mathrm{MHz}, \mathrm{CDCl}_{3}\right) \delta$ 7.51-7.36 (m, 5H), 6.01-5.87 (m, 2H), $5.54(\mathrm{~s}, 1 \mathrm{H}), 5.25(\mathrm{~d}, J=17.4 \mathrm{~Hz}, 1 \mathrm{H}), 5.21(\mathrm{dd}, J=17.7,10.2 \mathrm{~Hz}, 2 \mathrm{H}), 4.78(\mathrm{~d}$, $J=3.6 \mathrm{~Hz}, 1 \mathrm{H}), 4.37(\mathrm{dd}, J=12.6,5.7 \mathrm{~Hz}, 1 \mathrm{H}), 4.32-4.23(\mathrm{~m}, 3 \mathrm{H}), 4.18(\mathrm{dd}, J=12.9$, $6.6 \mathrm{~Hz}, 1 \mathrm{H}), 3.87(\mathrm{t}, 1 \mathrm{H}), 3.85-3.78(\mathrm{~m}, 1 \mathrm{H}), 3.72(\mathrm{t}, 1 \mathrm{H}), 3.55(\mathrm{t}, 1 \mathrm{H}), 3.47$ (dd, $J=9.3$, $3.9 \mathrm{~Hz}, 1 \mathrm{H}), 3.43(\mathrm{~s}, 3 \mathrm{H}),{ }^{13} \mathrm{CNMR}\left(75 \mathrm{MHz}, \mathrm{CDCl}_{3}\right) \delta$ 137.4, 135.2, 134.8, 128.9, 128.2, $126.0,117.7,116.7,101.3,99.3,82.1,79.0,77.9,73.9,73.1,69.1,62.3,55.2$. HRMS $\left(\mathrm{FAB}+\right.$ ) found $385.1627(\mathrm{M}+\mathrm{Na})\left(\right.$ calcd for $\mathrm{C}_{20} \mathrm{H}_{26} \mathrm{O}_{6} \mathrm{Na}$ : 385.1627). 
The diallyl benzylidene glucose derivative $(980 \mathrm{mg}, 2.70 \mathrm{mmol})$ was then dissolved in $\mathrm{MeOH}(32.0 \mathrm{~mL}) / \mathrm{H}_{2} \mathrm{O}$ (20 drops) followed by $p$-toluenesulfonic acid (130mg, $0.680 \mathrm{mmol})$. The reaction was heated to $60{ }^{\circ} \mathrm{C}$ for $3.5 \mathrm{~h}$ and then cooled to room temperature. Saturated $\mathrm{NaHCO}_{3}(20 \mathrm{~mL})$ was added to the reaction and then poured into separatory funnel containing $\mathrm{CH}_{2} \mathrm{Cl}_{2}(60 \mathrm{~mL})$. The organic layer was removed, and the aqueous layer was extracted with $\mathrm{CH}_{2} \mathrm{Cl}_{2}(60 \mathrm{~mL} \times 5)$. The combined organic layers were washed with brine, dried over $\mathrm{MgSO}_{4}$, filtered, and concentrated under vacuum. Purification by flash column chromatography on silica gel (Hexanes/EtOAc: 1/1 then 1/3) provided 0.741g (>99\%) of 5 as a thick pale yellow oil. ${ }^{1} \mathrm{HNMR}\left(300 \mathrm{MHz}, \mathrm{CDCl}_{3}\right)$ $\delta$ 6.02-5.86 (m, 2H), $5.30(\mathrm{~d}, J=16.8 \mathrm{~Hz}, 2 \mathrm{H}), 5.20(\mathrm{dd}, J=10.2,5.1 \mathrm{~Hz}, 2 \mathrm{H}), 4.78(\mathrm{~d}, J$ $=3.6 \mathrm{~Hz}, 1 \mathrm{H}), 4.45(\mathrm{dd}, J=12.6,5.4 \mathrm{~Hz}, 1 \mathrm{H}), 4.22(\mathrm{~d}, J=6.3 \mathrm{~Hz}, 1 \mathrm{H}), 4.20-4.12(\mathrm{~m}$, $3 \mathrm{H}), 3.90-3.75(\mathrm{~m}, 2 \mathrm{H}), 3.68-3.62(\mathrm{~m}, 2 \mathrm{H}), 3.52$ (apparent td, $J=9.3,2.7 \mathrm{~Hz}, 1 \mathrm{H}), 3.43$, (s, 3H), $3.38(\mathrm{dd}, J=9.6,3.6 \mathrm{~Hz}, 1 \mathrm{H}), 2.48(\mathrm{~d}, J=2.7 \mathrm{~Hz}, 1 \mathrm{H}), 1.96(\mathrm{t}, 1 \mathrm{H}) .{ }^{13} \mathrm{CNMR}$ $\left(75 \mathrm{MHz}, \mathrm{CDCl}_{3}\right) \delta 135.0,134.5,117.5,116.9,98.1,80.7,79.3,74.0,72.1,70.8,69.7$, 61.7, 55.0. HRMS $(F A B+)$ found $297.1313(\mathrm{M}+\mathrm{Na})$ (calcd for $\left.\mathrm{C}_{13} \mathrm{H}_{22} \mathrm{O}_{6} \mathrm{Na}: 297.1314\right)$. 


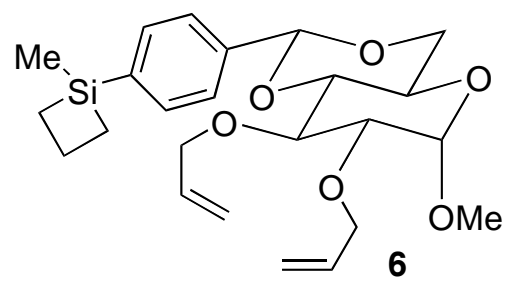

\section{Synthesis of PSP ether (6).}

Compound 5 (205mg, 0.75mmol), acetal $1(218 \mathrm{mg}, 0.92 \mathrm{mmol})$ and CSA (10.0mg, $0.043 \mathrm{mmol})$ were dissolved in $\mathrm{CH}_{2} \mathrm{Cl}_{2}(2.60 \mathrm{~mL})$. The reaction was heated to reflux for $6.5 \mathrm{~h}$ and was allowed to cool to room temperature. The reaction was then quenched with $\mathrm{Et}_{3} \mathrm{~N}(2.00 \mathrm{~mL})$ and was concentrated under vacuum. Purification by flash column chromatography on silica gel (Hexanes/EtOAc: 20/1, 8/1 then 6/1) provided $0.308 \mathrm{~g}$ (94\%) of 6 as a pale yellow oil. IR $v_{\max } \mathrm{cm}^{-1} 2928,2864,1373,1249,1178,1084,1054$, 995, 924, 866, 770. ${ }^{1} \mathrm{HNMR}\left(300 \mathrm{MHz}, \mathrm{CDCl}_{3}\right) \delta 7.64(\mathrm{~d}, J=8.1 \mathrm{~Hz}, 2 \mathrm{H}), 7.51(\mathrm{~d}, J=$ $7.8 \mathrm{~Hz}, 2 \mathrm{H}), 6.02-5.87(\mathrm{~m}, 2 \mathrm{H}), 5.55(\mathrm{~s}, 1 \mathrm{H}), 5.30(\mathrm{~d}, J=17.4 \mathrm{~Hz}, 2 \mathrm{H}), 5.18(\mathrm{dd}, J=$ 16.2, $11.7 \mathrm{~Hz}, 2 \mathrm{H}), 4.78(\mathrm{~d}, J=3.9 \mathrm{~Hz}, 1 \mathrm{H}), 4.37(\mathrm{dd}, J=12.6,5.7 \mathrm{~Hz}, 1 \mathrm{H}), 4.32-4.23$ (m, 3H), $4.19(\mathrm{dd}, J=12.9,6.6 \mathrm{~Hz}, 1 \mathrm{H}), 3.90-3.69(\mathrm{~m}, 3 \mathrm{H}), 3.55(\mathrm{t}, 1 \mathrm{H}), 3.49-3.45(\mathrm{~m}$, 1H), $3.43(\mathrm{~s}, 3 \mathrm{H}), 2.18(\mathrm{q}, 2 \mathrm{H}), 1.34-1.11(\mathrm{~m}, 4 \mathrm{H}), 0.54(\mathrm{~s}, 3 \mathrm{H}) .{ }^{13} \mathrm{CNMR}(75 \mathrm{MHz}$, $\left.\mathrm{CDCl}_{3}\right) \delta 139.5,138.4,135.2,134.8,133.4,133.3,125.4,117.6,116.7,101.1,99.2,82.0$ 79.0, 77.9, 73.9, 73.0, 69.0, 62.3, 55.2, 18.2, 14.3, -1.73. HRMS (FAB+) found 469.2026 $\left(\mathrm{M}+\mathrm{Na}\right.$ ) (calcd for $\mathrm{C}_{24} \mathrm{H}_{34} \mathrm{O}_{6} \mathrm{SiNa}$ : 469.2022). 


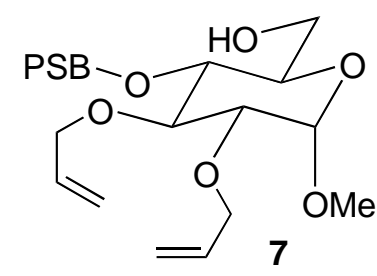

\section{Synthesis of PSB ether (7).}

Compound 6 (54.5mg, $0.120 \mathrm{mmol})$ was dissolved in $\mathrm{CH}_{2} \mathrm{Cl}_{2}(1.30 \mathrm{~mL})$ and the solution was cooled to $-78{ }^{\circ} \mathrm{C}$ in an acetone/dry-ice bath for $5 \mathrm{~min}$. DIBAL-H in $1.0 \mathrm{M}$ heptane $(1.30 \mathrm{~mL}, 1.30 \mathrm{mmol})$ was added dropwise at $-78{ }^{\circ} \mathrm{C}$, and the mixture was warmed to -13 ${ }^{\circ} \mathrm{C}$ in the freezer for $15 \mathrm{~h}$. $\mathrm{HCl}(1.0 \mathrm{M}, 20 \mathrm{~mL})$ was added at $0{ }^{\circ} \mathrm{C}$ to quench excess of DIBAL-H, and the organic layer was removed. The aqueous layer was extracted with $\mathrm{CH}_{2} \mathrm{Cl}_{2}(20 \mathrm{~mL} \times 2)$, and the combined organic layers were washed with saturated $\mathrm{NaHCO}_{3}$, brine, dried over $\mathrm{MgSO}_{4}$, filtered and concentrated under vacuum. Purification by flash column chromatography on silica gel (Hexanes/EtOAc: 6/1, 3/1) provided $0.0442 \mathrm{~g}(81 \%)$ of 7 as a thick yellow oil. Byproduct compound 8 was obtained $0.0080 \mathrm{~g}$ (15\%) as a thick yellow oil. IR $v_{\max } \mathrm{cm}^{-1} 3468,2924,1646,1390,1080,924,867,769$. ${ }^{1} \mathrm{HNMR}(7)\left(300 \mathrm{MHz}, \mathrm{CDCl}_{3}\right) \delta 7.62(\mathrm{~d}, J=8.1 \mathrm{~Hz}, 2 \mathrm{H}), 7.37(\mathrm{~d}, J=7.8 \mathrm{~Hz}, 2 \mathrm{H}), 6.05-$ $5.87(\mathrm{~m}, 2 \mathrm{H}), 5.30(\mathrm{dd}, J=17.1,1.5 \mathrm{~Hz}, 2 \mathrm{H}), 5.18(\mathrm{dd}, J=10.5,1.2 \mathrm{~Hz}, 2 \mathrm{H}), 4.91(\mathrm{~d}, J=$ $11.1 \mathrm{~Hz}, 1 \mathrm{H}), 4.75(\mathrm{~d}, J=3.6 \mathrm{~Hz}, 1 \mathrm{H}), 4.66(\mathrm{~d} J=11.1 \mathrm{~Hz}, 1 \mathrm{H}), 4.41(\mathrm{dd}, J=12.3,5.7$ $\mathrm{Hz}, 1 \mathrm{H}), 4.29$ (dd, $J=12.3,5.4 \mathrm{~Hz}, 1 \mathrm{H}), 4.22-4.12(\mathrm{~m}, 2 \mathrm{H}), 3.85-3.71(\mathrm{~m}, 3 \mathrm{H}), 3.66-3.60$ (m, 1H), 3.49 (t, 1H), 3.39 (dd, J = 6.9, $3.9 \mathrm{~Hz}, 2 \mathrm{H}), 3.39$ (s, 3H), 2.18 (q, 2H), 1.33-1.11 (m, 4H), $0.54(\mathrm{~s}, 3 \mathrm{H}) .{ }^{13} \mathrm{CNMR}\left(75 \mathrm{MHz}, \mathrm{CDCl}_{3}\right) \delta 139.4,138.3,135.2,134.8,133.7$, $127.5,117.7,116.6,98.3,81.5,79.7,74.9,74.3,72.6,70.6,61.9,55.1,18.2,14.3,-1.69$. HRMS (FAB+) found $471.2176(\mathrm{M}+\mathrm{Na})\left(\right.$ calcd for $\mathrm{C}_{24} \mathrm{H}_{36} \mathrm{O}_{6} \mathrm{SiNa}$ : 471.2179). 
${ }^{1} \mathrm{HNMR}(8)\left(300 \mathrm{MHz}, \mathrm{CDCl}_{3}\right) \delta 7.61(\mathrm{~d}, J=7.5 \mathrm{~Hz}, 2 \mathrm{H}), 7.37(\mathrm{~d}, J=7.8 \mathrm{~Hz}, 2 \mathrm{H}), 6.03$ $5.85(\mathrm{~m}, 2 \mathrm{H}), 5.32(\mathrm{dd}, J=4.2,1.8 \mathrm{~Hz}, 1 \mathrm{H}), 5.26(\mathrm{dd}, J=4.2,1.2 \mathrm{~Hz}, 1 \mathrm{H}), 5.19(\mathrm{dd}, J=$ $10.2,1.8 \mathrm{~Hz}, 2 \mathrm{H}), 4.80(\mathrm{~d}, J=3.3 \mathrm{~Hz}, 1 \mathrm{H}), 4.61(\mathrm{~d}, J=6.0 \mathrm{~Hz}, 2 \mathrm{H}), 4.43(\mathrm{dd}, J=12.6$, $5.4 \mathrm{~Hz}, 1 \mathrm{H}), 4.22$ (dd, $J=12.6,6.0 \mathrm{~Hz}, 2 \mathrm{H}), 4.18-4.13$ (m, 2H), 3.72 (bs, 3H), 3.70-3.59 (m, 2H), 3.44-3.38 (m, 1H, s, 3H), $2.18(\mathrm{q}, 2 \mathrm{H}), 1.34-1.14(\mathrm{~m}, 4 \mathrm{H}), 0.55(\mathrm{~s}, 3 \mathrm{H})$.

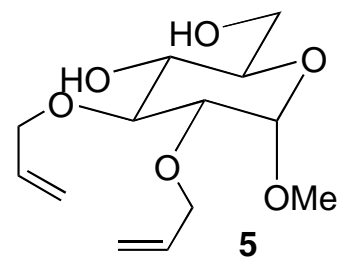

Oxidative deprotection of PSB ether (7) to diol (5).

$\mathrm{KF} \cdot 2 \mathrm{H}_{2} \mathrm{O}(42.0 \mathrm{mg}, 0.446 \mathrm{mmol})$ and $\mathrm{KHCO}_{3}(44.6 \mathrm{mg}, 0.445 \mathrm{mmol})$ were added to a solution of 7 (100mg, $0.223 \mathrm{mmol})$ in $1.71 \mathrm{~mL}$ of $\mathrm{THF} / \mathrm{CH}_{3} \mathrm{OH}(1: 1)$. The resulting mixture was cooled in an ice bath, and $\mathrm{H}_{2} \mathrm{O}_{2}\left(30 \%\right.$ in $\left.\mathrm{H}_{2} \mathrm{O}, 0.228 \mathrm{~g}, 6.68 \mathrm{mmol}\right)$ was added dropwise. The reaction mixture was stirred at $0{ }^{\circ} \mathrm{C}$ for $10 \mathrm{~min}$ and then at ambient temperature for $6 \mathrm{~h}$. The reaction mixture was then diluted with EtOAc $(5.0 \mathrm{~mL})$ and the aqueous layer removed. The organic phase was sequentially washed with a $1.0 \mathrm{M}$ aqueous $\mathrm{Na}_{2} \mathrm{~S}_{2} \mathrm{O}_{3}(2.0 \mathrm{~mL})$ and brine $(2.0 \mathrm{~mL})$. The combined aqueous phases were extracted with $\mathrm{CH}_{2} \mathrm{Cl}_{2}(5.0 \mathrm{~mL} \times 3)$. The combined organic phases were dried over $\mathrm{Na}_{2} \mathrm{SO}_{4}$, filtered and concentrated under vacuum to provide $0.0879 \mathrm{~g}$ of a yellow oil (104\% of theoretical yield), which was used without further purification. ${ }^{1}$ HNMR $\left(300 \mathrm{MHz}, \mathrm{CDCl}_{3}\right) \delta 7.22(\mathrm{~d}, J=8.4 \mathrm{~Hz}, 2 \mathrm{H}), 6.80(\mathrm{~d}, J=8.4 \mathrm{~Hz}, 2 \mathrm{H}), 6.07-5.86(\mathrm{~m}, 2 \mathrm{H})$, $5.33(\mathrm{dd}, J=4.8,1.5 \mathrm{~Hz}, 1 \mathrm{H}), 5.27(\mathrm{dd}, J=4.8,1.5 \mathrm{~Hz}, 1 \mathrm{H}), 5.19(\mathrm{t}, 2 \mathrm{H}), 4.81(\mathrm{t}, 2 \mathrm{H})$, $4.74(\mathrm{~d}, J=3.6 \mathrm{~Hz}, 1 \mathrm{H}), 4.56(\mathrm{~d}, J=5.4 \mathrm{~Hz}, 1 \mathrm{H}), 4.41(\mathrm{dd}, J=12.3,5.4 \mathrm{~Hz}, 1 \mathrm{H}), 4.29$ 
$(\mathrm{dd}, \mathrm{J}=12.6,5.7 \mathrm{~Hz}, 1 \mathrm{H}), 4.21-4.11(\mathrm{~m}, 2 \mathrm{H}), 3.83-3.68(\mathrm{~m}, 3 \mathrm{H}), 3.62-3.57(\mathrm{~m}, 1 \mathrm{H})$, 3.52-3.45 (m, 2H), 3.41-3.35 (m, 2H, s, 3H), 1.67 (dd, $J=7.2,5.4 \mathrm{~Hz}, 1 \mathrm{H})$.

A portion of the above mixture $(40.0 \mathrm{mg}, 0.105 \mathrm{mmol})$ was dissolved in $\mathrm{Et}_{2} \mathrm{O}(1.17 \mathrm{~mL})$ and then cooled to $0{ }^{\circ} \mathrm{C}$ for 5 min. under argon. Anhydrous $\mathrm{FeCl}_{3}(25.6 \mathrm{mg}, 0.158 \mathrm{mmol})$ was added to the solution, and the temperature was maintained at $0{ }^{\circ} \mathrm{C}$ for $1 \mathrm{~h}$. The reaction was monitored by TLC. Water $(1.0 \mathrm{~mL})$ was added to quench the reaction, and the mixture was then extracted with $\mathrm{CH}_{2} \mathrm{Cl}_{2}(5.0 \mathrm{~mL}$ x 2). The organic layer was washed with brine, dried over $\mathrm{Na}_{2} \mathrm{SO}_{4}$, filtered and concentrated under vacuum. Purification by flash column chromatography on silica gel (Hexanes/EtOAc: 1/2) provided $0.0203 \mathrm{~g}$ (73\% from 7 ) of compound 5 as a thick pale yellow oil.

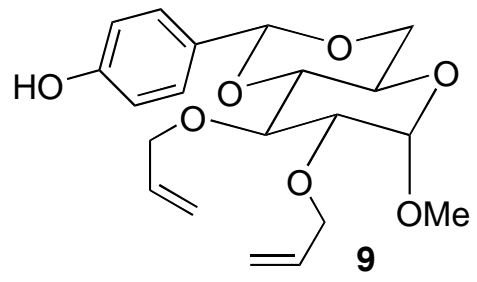

\section{Oxidation of the PSP acetal $(6 \rightarrow 9)$; deprotection of 9.}

$\mathrm{KF} \cdot 2 \mathrm{H}_{2} \mathrm{O}(160 \mathrm{mg}, 1.79 \mathrm{mmol})$ and $\mathrm{KHCO}_{3}(179 \mathrm{mg}, 1.79 \mathrm{mmol})$ were added to a solution of $6(400 \mathrm{mg}, 0.896 \mathrm{mmol})$ in $6.89 \mathrm{~mL}$ of $\mathrm{THF} / \mathrm{CH}_{3} \mathrm{OH}(1: 1)$. The resulting mixture was cooled in an ice bath, and $\mathrm{H}_{2} \mathrm{O}_{2}\left(30 \%\right.$ in $\left.\mathrm{H}_{2} \mathrm{O}, 0.914 \mathrm{~g}, 26.9 \mathrm{mmol}\right)$ was added dropwise. The reaction mixture was stirred at $0{ }^{\circ} \mathrm{C}$ for $10 \mathrm{~min}$ and then at ambient temperature for 6 h. The reaction mixture was then diluted with EtOAc $(10.0 \mathrm{~mL})$ and the aqueous layer removed. The organic phase was sequentially washed with a $1.0 \mathrm{M}$ aqueous $\mathrm{Na}_{2} \mathrm{~S}_{2} \mathrm{O}_{3}$ (5.0mL) and brine $(5.0 \mathrm{~mL})$. The combined aqueous phases were extracted with $\mathrm{CH}_{2} \mathrm{Cl}_{2}$ (10.0mL x 3). The combined organic phases were dried over $\mathrm{Na}_{2} \mathrm{SO}_{4}$, filtered and 
concentrated under vacuum. Purification by flash column chromatography on silica gel (Hexanes/EtOAc: $1 / 2)$ provided $0.260 \mathrm{~g}(77 \%)$ of 9 as a pale yellow oil. ${ }^{1}$ HNMR (9) $\left(300 \mathrm{MHz}, \mathrm{CDCl}_{3}\right) \delta 7.36(\mathrm{~d}, J=8.4 \mathrm{~Hz}, 2 \mathrm{H}), 6.81(\mathrm{~d}, J=8.7 \mathrm{~Hz}, 2 \mathrm{H}), 6.00-5.86(\mathrm{~m}, 2 \mathrm{H})$, $5.47(\mathrm{~s}, 1 \mathrm{H}), 5.32(\mathrm{dd}, J=3.6,1.8 \mathrm{~Hz}, 1 \mathrm{H}), 5.26(\mathrm{dd}, J=3.6,1.5 \mathrm{~Hz}, 1 \mathrm{H}), 5.20(\mathrm{~d}, J=$ $10.2 \mathrm{~Hz}, 1 \mathrm{H}), 5.14(\mathrm{~d}, J=10.5 \mathrm{~Hz}, 1 \mathrm{H}), 4.82(\mathrm{bs}, 1 \mathrm{H}), 4.77(\mathrm{~d}, J=3.6 \mathrm{~Hz}, 1 \mathrm{H}), 4.38-4.15$ (m, 5H), 3.89-3.66(m, 3H), 3.55-3.45 (m, 2H), $3.43(\mathrm{~s}, 3 \mathrm{H})$.

The compound 9 (51.5mg, $0.136 \mathrm{mmol})$ was dissolved in $\mathrm{Et}_{2} \mathrm{O}(1.51 \mathrm{~mL})$ and then cooled to $0{ }^{\circ} \mathrm{C}$ for $5 \mathrm{~min}$. under argon. Anhydrous $\mathrm{FeCl}_{3}(33.1 \mathrm{mg}, 0.204 \mathrm{mmol})$ was added to the solution, and the temperature was maintained at $0{ }^{\circ} \mathrm{C}$ for $1 \mathrm{~h}$. The reaction was monitored by TLC. Water $(1.0 \mathrm{~mL})$ was added to quench the reaction, and the mixture was then extracted with $\mathrm{CH}_{2} \mathrm{Cl}_{2}(5.0 \mathrm{~mL} \times 2)$. The organic layer was washed with brine, dried over $\mathrm{Na}_{2} \mathrm{SO}_{4}$, filtered and concentrated under vacuum. Purification by flash column chromatography on silica gel (Hexanes/EtOAc: 1/2) provided $0.0203 \mathrm{~g}(62 \%)$ of compound 5 as a thick pale yellow oil.

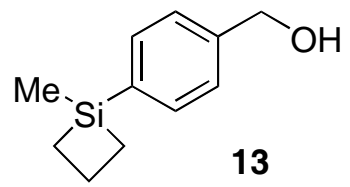

\section{Synthesis of alcohol (13). ${ }^{1}$}

Aldehyde 12 (895mg, 4.68mmol) was dissolved in $\mathrm{CH}_{2} \mathrm{Cl}_{2}(15.0 \mathrm{~mL})$ and cooled to -78 ${ }^{\circ} \mathrm{C}$ for $5 \mathrm{~min}$. DIBAL-H in $1.0 \mathrm{M}$ dichloromethane $(9.50 \mathrm{~mL}, 9.50 \mathrm{mmol})$ was added dropwise at $-78{ }^{\circ} \mathrm{C}$, and the mixture was warmed to rt for $2 \mathrm{~h}$. $1.0 \mathrm{M} \mathrm{HCl}(100 \mathrm{~mL})$ was added at $0{ }^{\circ} \mathrm{C}$ to quench the reaction, and the organic layer was removed. The aqueous layer was extracted with $\mathrm{CH}_{2} \mathrm{Cl}_{2}(25.0 \mathrm{~mL} \times 2)$, and the combined organic layers were 
washed with saturated $\mathrm{NaHCO}_{3}$, brine, dried over $\mathrm{MgSO}_{4}$, filtered and concentrated under vacuum. Purification by flash column chromatography on silica gel (Hexanes/EtOAc: 3/1) provided alcohol 13 in 87\% yield. ${ }^{2}$

para-siletanylbenzylidene acetal (1)
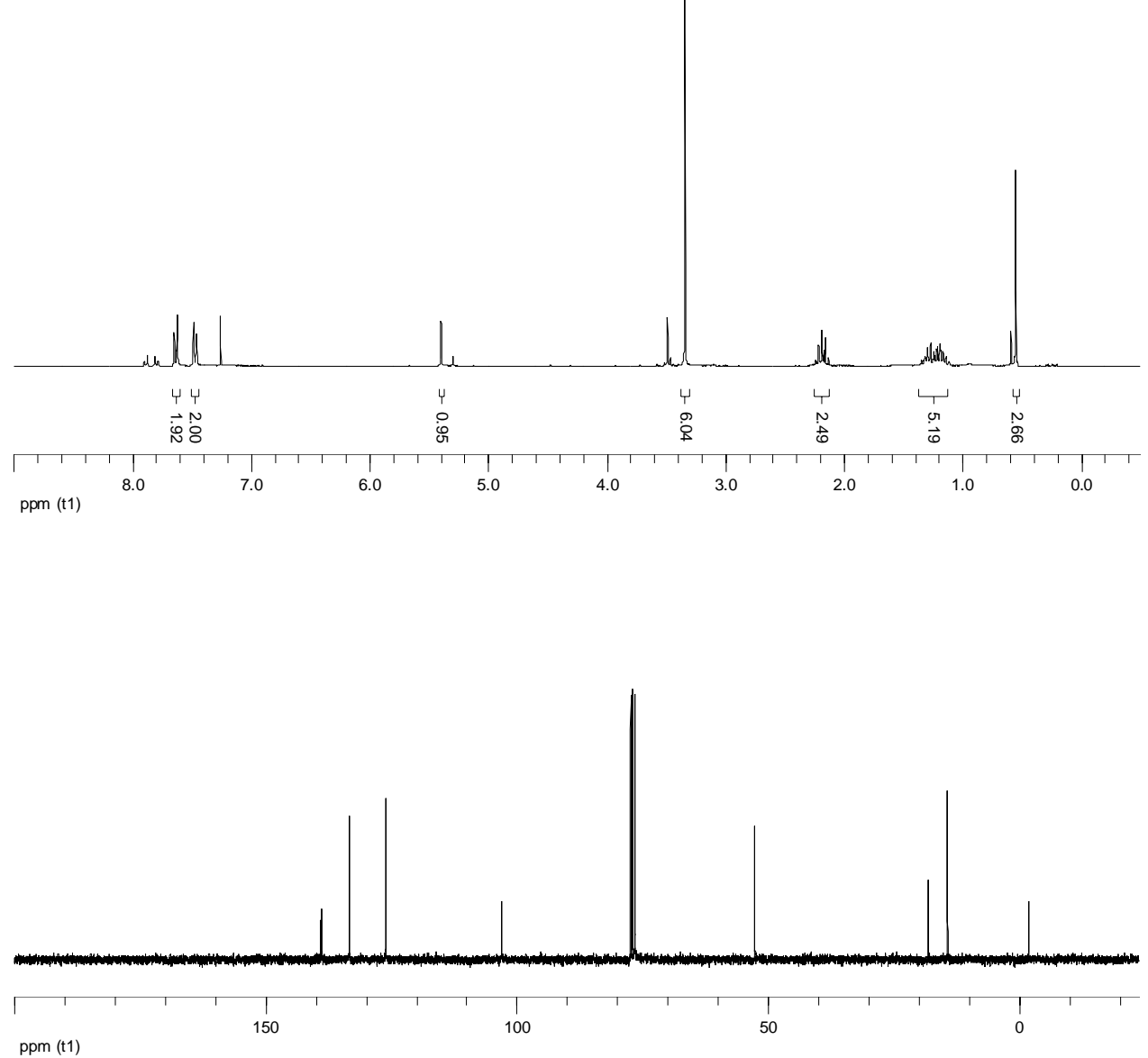
benzylidene acetal (3)
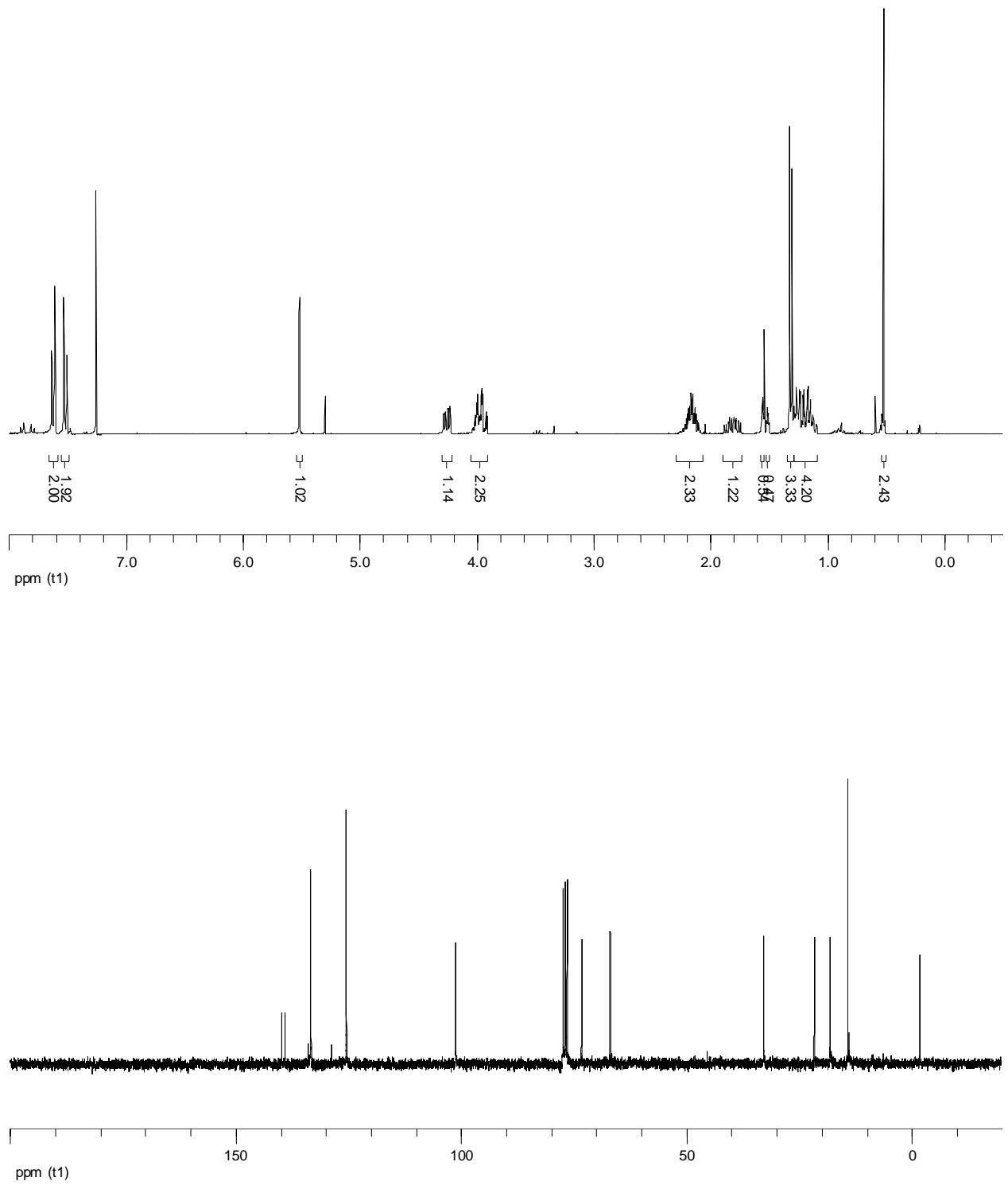
alcohol (4)
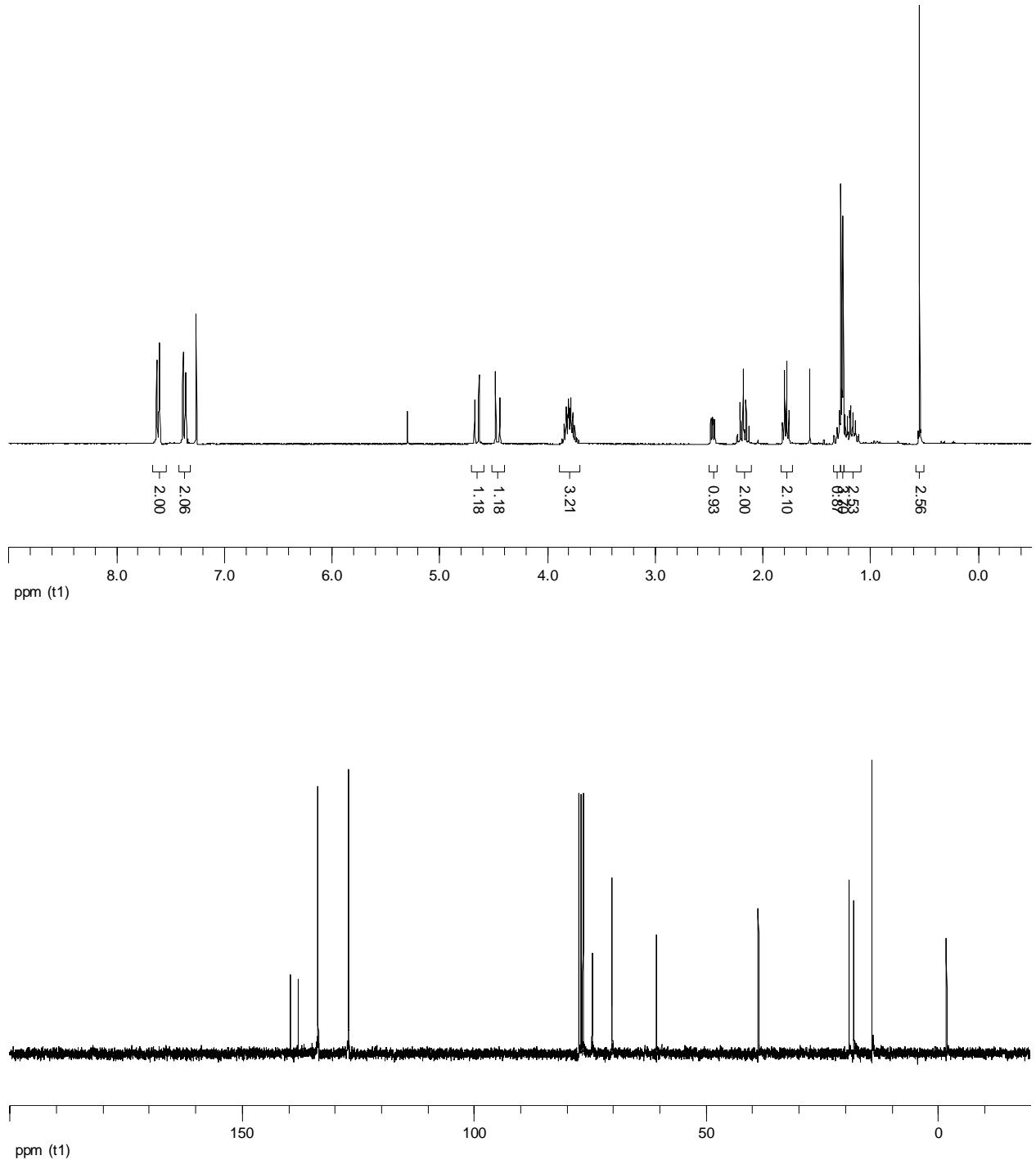


\section{diallylmethyl glucopyranoside (5)}
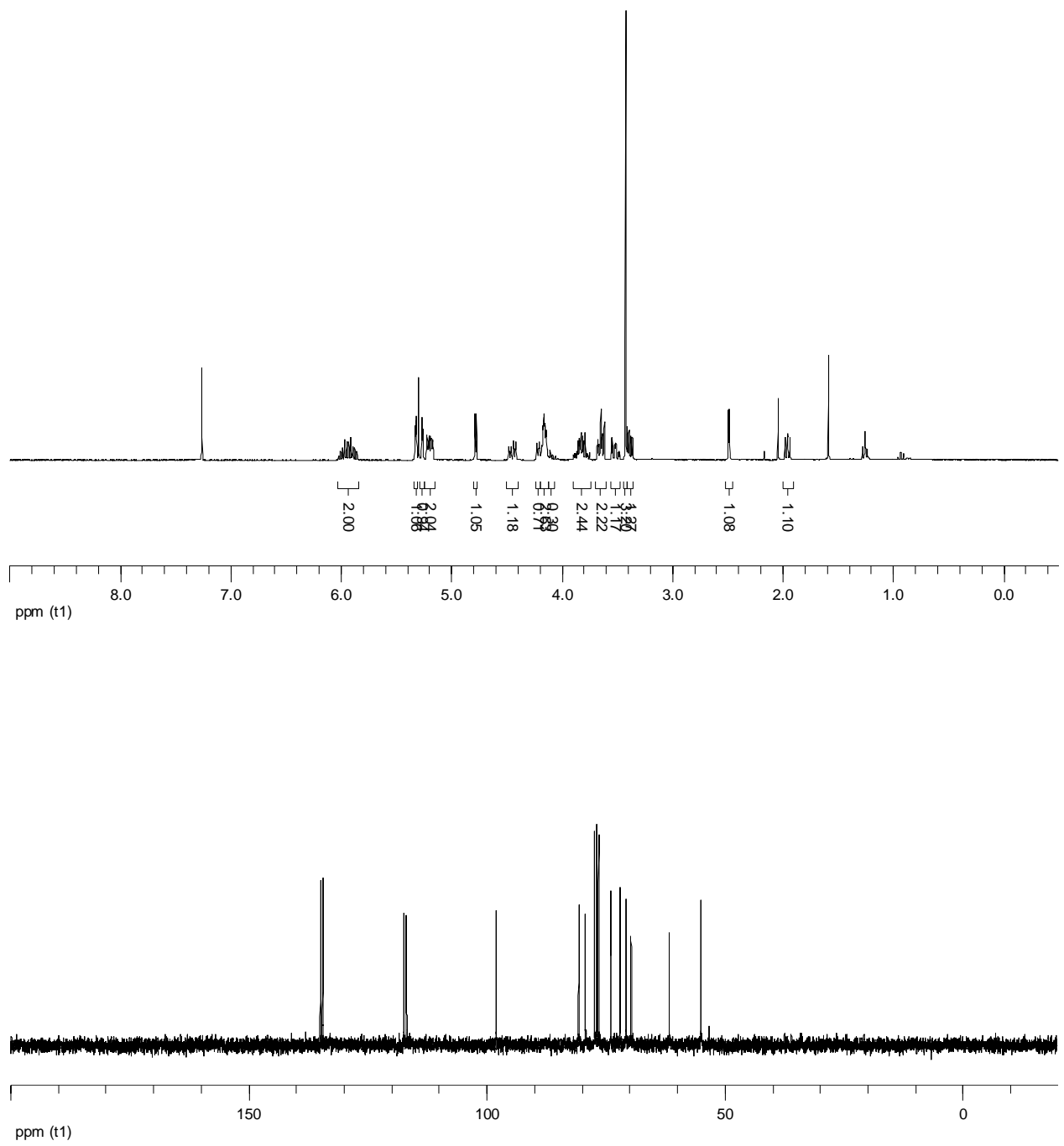


\section{PSP ether (6)}
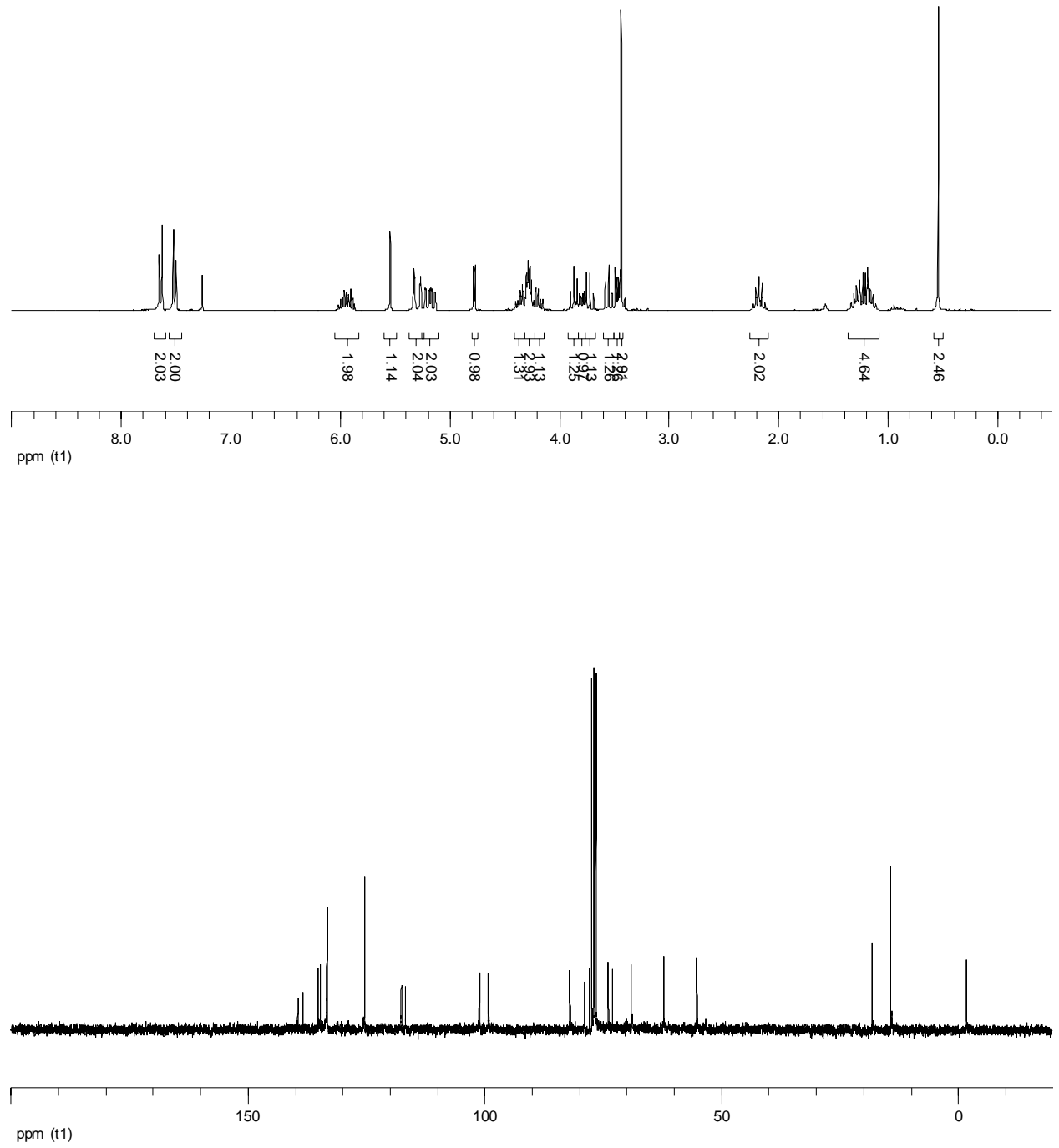


\section{PSB ether (7)}
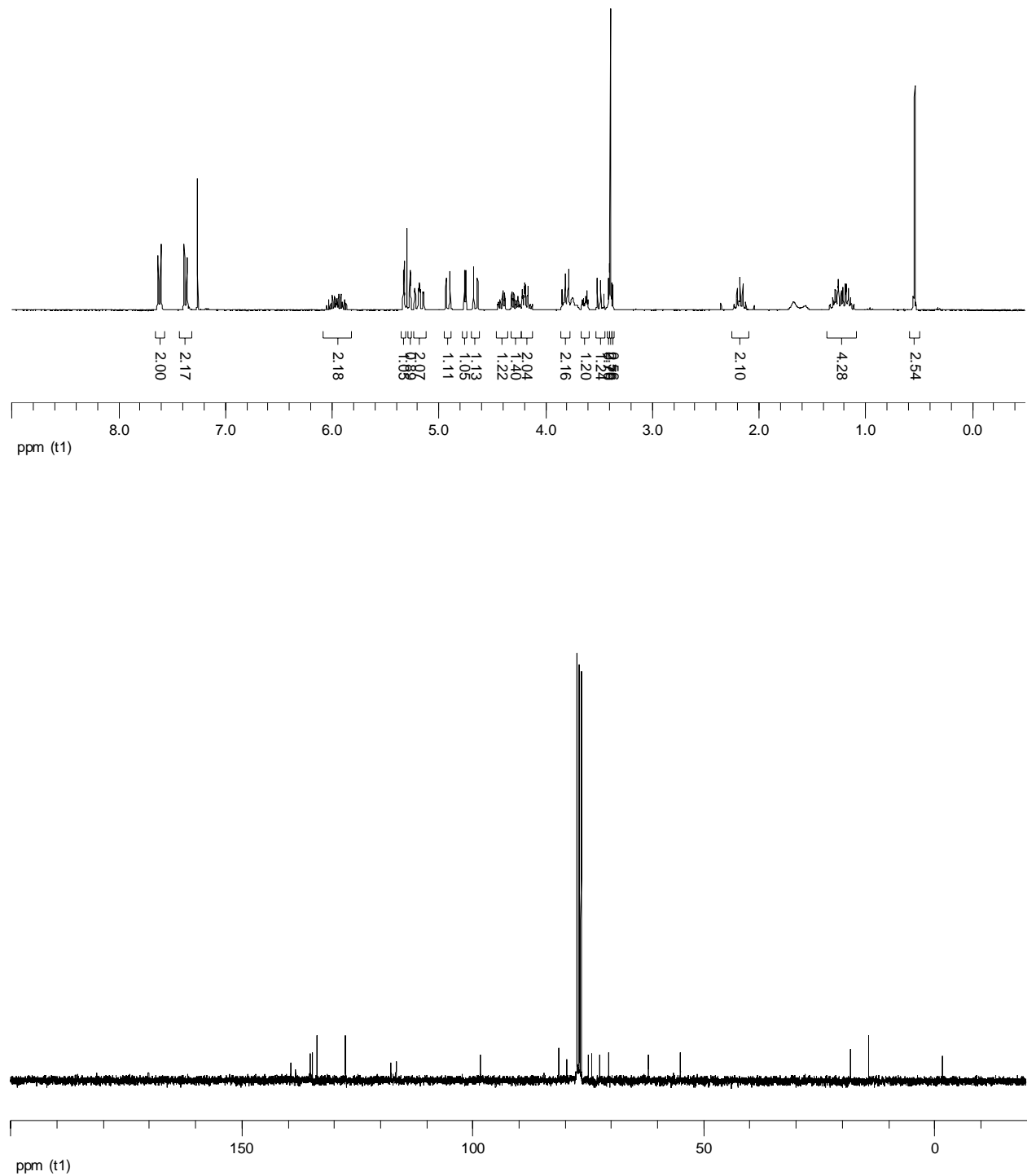

\footnotetext{
${ }^{1}$ Aldehyde 12 used for this experiment was prepared within the context of a related (unpublished) project in our Lab. As depicted in the text, acetal 1 was stirred in a 1:1 biphasic mixture of $\mathrm{Et}_{2} \mathrm{O}$ and $1 \mathrm{M}$ aqueous $\mathrm{HCl}$ to effect complete conversion to aldehyde $\mathbf{1 2}$ within 5 hours. The yield of $\mathbf{1} \rightarrow \mathbf{1 2}$ as estimated by ${ }^{1} \mathrm{H}$ NMR (using $p$-anisaldehyde as an internal standard) was $95 \%$.

${ }^{2}$ Lam, H.; House, S. E.; Dudley, G. B. Tetrahedron Lett. 2005, 46, 3283-3285.
} 